Agnieszka Golczyńska-Grondas

Matgorzata Potoczna

Katedra Socjologii Stosowanej i Pracy Socjalnej

Uniwersytet Łódzki

\title{
ZNACZENIE BADAŃ BIOGRAFICZNYCH W ANALIZACH UBÓSTWA I WYKLUCZENIA SPOŁECZNEGO
}

\section{WPROWADZENIE}

Ubóstwo i związane z nim procesy marginalizacji społecznej ${ }^{1}$ stanowią immanentną cechę życia społecznego. Przyczyny obu zjawisk, ich zasięg oraz konsekwencje były i są warunkowane historycznie ${ }^{2}$ i geograficznie, również obecnie fenomeny te postrzega się, definiuje, wartościuje, mierzy i bada w ramach ich uwarunkowań o charakterze przestrzenno-temporalnym. Jednocześnie od późnego średniowiecza do dnia dzisiejszego poszukuje się środków, jakie zaradzić mają biedzie, poczynając od miłosierdzia i filantropii o charakterze religijnym, poprzez próby kontrolowania zbiorowości ubogich i prawnego regulowania ich statusu, do bardziej współczesnych rozwiązań, takich jak polityka welfare state czy globalne programy pomocowe. Łatwo zauważyć, że proponowane formy oddziaływań stosowano i nadal stosowane są w zależności od funkcjonujących w danej

\footnotetext{
${ }^{1}$ Przyjmuje się, że marginalizacja jest procesem społecznym, marginalność oznacza stan, a termin ekskluzja stosowany być może zarówno w odniesieniu do stanu, jak i procesu (Kowalak: 16-30). Nie są przy tym jednoznacznie zdefiniowane granice terminu wykluczenie społeczne (Tarkowska, 2006: 340 i n.). Pojęć ekskluzji społecznej, marginalizacji społecznej i wykluczenia społecznego w związku z ich bliskoznacznością - ze względów stylistycznych - używamy zamiennie, ze świadomością różnic o charakterze definicyjnym. Ponadto, w tekście niniejszym odnosimy się wyłącznie do wykluczenia społecznego powiązanego z ubóstwem, choć w sposób oczywisty ekskluzja stanowić może rezultat różnych uwarunkowań.

${ }^{2}$ Nie zawsze ten, kto był biedny lokował się jednocześnie poza marginesem społeczeństwa. Np. w wiekach średnich ubóstwo traktowane było jako przymiot jednostki poprzez ascezę dążącej do osiągnięcia zbawienia, nadzieję na zabawienie żywili także ci, którzy świadczyli biednym miłosierdzie. Biedny funkcjonował więc w strukturze średniowiecznego społeczeństwa, na marginesie którego znajdowali się natomiast tzw. ludzie luźni. Jednakże już w XII-XIII w., w związku ze wzrostem liczby ubogich i rozpowszechnieniem się zjawiska żebractwa i włóczęgostwa (rezultat wielkich epidemii, wojen, przeludnienia wsi, etc.), bieda zaczyna być postrzegana jako zagrożenie porządku społecznego (Czarnowski, 1982: 200-201, Geremek, 1989; Leś, 2000).
} 
zbiorowości modeli wyjaśniania i konceptualizacji przyczyn biedy i wykluczenia społecznego (Warzywoda-Kruszyńska 1996: 21-26; Warzywoda-Kruszyńska 2001: 21-24; Tarkowska 2000: 9-17, Frieske 1999: 7-27). Jednakże, pomimo licznych podejmowanych przez wieki działań nigdy nie udało się w skuteczny sposób zlikwidować zjawiska biedy i wydaje się, że będzie ono nadal fenomenem w sposób trwały wpisanym w życie współczesnych społeczeństw.

Współczesne badania biedy i wykluczenia społecznego realizowane są zarówno w wymiarze makro-, mezzo-, jak i mikrospołecznym. Po pierwsze, analizowane są np. związki między procesami historycznymi i makrostrukturalnymi a procesami pauperyzacji, po drugie, uwagę badaczy przyciągają zjawiska przestrzennej koncentracji ludności zubożałej, po trzecie, nie mniej znaczące w stosunku do powyższych są badania ukazujące biedę i wykluczenie społeczne jako doświadczenie o charakterze indywidualnym, skutki procesów pauperyzacyjnych odczuwają bowiem w sposób rzeczywisty jednostki i rodziny. W badaniach tych we wszystkich wymienionych wymiarach szerokie zastosowanie znajduje metoda biograficzna oferująca szeroki zakres technik zbierania materiałów, takich jak wywiady biograficzne, family-life histories (cases histories of families), retrospektywne wywiady pogłębione wywodzące się z tradycji oral history, pamiętniki i dokumenty osobiste, a także źródła zastane, gromadzone przez różnego rodzaju instytucje, w których polu oddziaływań znalazła się jednostka lub rodzina ${ }^{3}$ (Bertaux 1995; Tarkowska 2000, 2007; Warzywoda-Kruszyńska 2001b).

Tekst niniejszy powstał na podstawie naszych doświadczeń związanych z uczestnictwem w pracach badawczych zespołu Łódzkiej Szkoły Badań nad Biedą i Pomocą Społeczną kierowanego przez profesor Wielisławę Warzywodę-Kruszyńską. W pierwszej części artykułu piszemy o początkach oraz współczesnym zastosowaniu metody biograficznej $\mathrm{w}$ analizach zbiorowości defaworyzowanych. W drugiej części tekstu, (opierając się, przede wszystkim, na powstałych po roku 1989 pracach polskich autorów), odnosimy się do kwestii znaczenia badań biograficznych dla rozwoju refleksji socjologicznej, zarówno w obszarze analiz ubóstwa i wykluczenia społecznego, jak i innych subdyscyplin tej nauki.

\section{KILKA UWAG O HISTORII ZASTOSOWANIA MATERIALÓW BIOGRA- FICZNYCH W KONTEKŚCIE PROCESÓW EKSKLUZYJNYCH}

Metoda biograficzna właściwie od momentu, w którym odkryto jej znaczenie dla obszaru badań społecznych, stosowana była do analiz zjawisk dezintegracji społecznej i jej rozlicznych konsekwencji (bieda, bezrobocie, zachowania

${ }^{3} \mathrm{~W}$ ramach metody biograficznej w sposób zasadny naszym zdaniem umieścić można także analizy przebiegu życia traktowane przez niektórych autorów jako odrębny nurt badawczy, a nawet odrębna subdyscyplina socjologiczna (Dobrowolska 1992: 75). 
anormatywne), zgodnie z dzisiejszą terminologią lokowanych w obszarze wykluczenia społecznego. Pierwszą powszechnie znaną pracą socjologiczną wykorzystującą wieloaspektowo metodę biograficzną jest pięciotomowe dzieło W. I. Thomasa i F. Znanieckiego Chłop polski w Europie i Ameryce wydane w latach 1918-19204. Opracowanie Thomasa i Znanieckiego poświęcone było fali wielkiej emigracji chłopskiej na przełomie XIX i XX w. Autorzy wykorzystali listy zbierane „seriami rodzinnymi” w dłuższym okresie, protokoły różnego rodzaju instytucji i agencji zajmujących się problemami społecznymi, protokoły sądowe, materiały prasowe, zapiski w dokumentach parafialnych. Na zamówienie autorów powstał także Pamiętnik imigranta zamieszczony wraz z omówieniem w tomie III. Można uznać, iż opracowanie zawierające teoretyczne wyjaśnienia procesu przemian i dezorganizacji społecznej oraz powiązanych z nimi procesów jednostkowych, przemian osobowości i procesów przystosowania w sposób bardzo wyraźny mieści się w zakresie analiz ekskluzji społecznej ${ }^{5}$ (Thomas, Znaniecki 1976; Szczepański 1976: 34-35).

W 2. i 3. dekadzie XX w. Thomas i inni badacze Szkoły Chicago (m.in. N. Anderson, W. Healy i A. Bronner, C.R. Shaw i M.E. Moore) wykorzystywali metodę biograficzną ${ }^{6} \mathrm{~W}$ monografiach zbiorowości funkcjonujących na marginesie społeczeństwa - niedostosowanych społecznie dziewcząt i chłopców, bezdomnych, członków gangów ${ }^{7}$. Opierano się na założeniu, że opowiadająca swoją historię jednostka stanowi typowy przykład danej grupy społecznej poprzez sam fakt bycia jej członkiem, a także przez przyswojenie sobie celów i aktywności, języka i tradycji oraz standardówi praktyk grupy (Burgess 1966:185-186). Badacze chicagowscy udowodnili, iż autobiografie, pamiętniki, listy i inne dokumenty osobiste znakomicie odzwierciedlają złożoność losów jednostki we współczesnym świecie oraz kompleksowość środowisk i światów społecznych (Riemann 2003: 2).

\footnotetext{
${ }^{4}$ Opracowanie to przetłumaczone zostało na język polski dopiero na początku lat 70 . Ukazało się w roku 1976 nakładem Ludowej Spółdzielni Wydawniczej (Thomas, Znaniecki 1976).

${ }^{5}$ Problematyka ta obecna jest we wszystkich pięciu tomach, szczególne znaczenie mają wspomniany tom III i ostatni. W części tomu V, zatytułowanej Dezorganizacja imigranta omówiono kolejno kwestie: demoralizacji, niezdolności do zarobkowania, rozkładu małżeństwa i zachowań anormatywnych (morderstwo, włóczęgostwo, przestępczość wśród chłopców, niemoralność seksualna wśród dziewcząt), (Thomas, Znaniecki 1976).

${ }^{6}$ Gerhard Riemann zwraca uwagę na to, że metody biograficznej używano w Szkole Chicago w sposób nieortodoksyjny (Riemann 2003: 2).

${ }^{7}$ Jak pisze E. Hałas, już pod koniec XIX w. „Wielkie miasto było dla socjologów z Chicago naturalnym laboratorium, albo też żywym modelem [...] case study szerszych problemów porządku społecznego" (Hałas 1994: 7).
} 
Analizy ubóstwa zyskały szczególne znaczenie w okresie Wielkiego Kryzysu lat 30. Jednym ze znaczących przykładów są tu badania prowadzone w austriackim Marienthalu. W tym okresie, po raz pierwszy w Polsce, w warszawskim Instytucie Gospodarstwa Społecznego zastosowano metodę biograficzną w analizach problemów biedy. W roku 1931 w Instytucie tym ogłoszono konkurs na pamiętniki osób bezrobotnych. We wstępie do I (jedynego opublikowanego) tomu ${ }^{8}$ L. Krzywicki wymieniał dewastujące konsekwencje bezrobocia dla jednostek, rodzin i społeczeństwa podkreślając, że dzięki publikacji pamiętników skala problemów oraz narastający gniew ich autorów zwrócą uwagę polityków i zwykłych ludzi budząc ich sumienia i powodując podjęcie działań zaradczych ${ }^{9}$ (Krzywicki 1933: VI; Sułek 2011:63). Konkurs Instytutu Gospodarstwa Społecznego stanowił inspirację dla wydania w roku 1934 w Londynie pamiętników angielskich bezrobotnych, redaktorami Memoirs of Unemployment byli H.L. Beales i R.S. Lambert. Badania bezrobocia przy użyciu metody biograficznej kontynuowano w naszym kraju do wybuchu II wojny światowej. Między innymi w drugiej połowie lat 30., w Polskim Instytucie Socjologicznym w Poznaniu zebrano pod kierownictwem F. Znanieckiego ponad 600 autobiografii napisanych przez osoby bezrobotne (Sułek 2011: 56-80).

W okresie powojennym spadło zainteresowanie wykorzystywaniem materiałów biograficznych w badaniach społecznych. Znaczenie metody biograficznej doceniono ponownie w latach 60. ubiegłego wieku. Na przykład w Polsce, w tym czasie nawiązano kontakt $\mathrm{z}$ autorami przedwojennych pamiętników bezrobotnych, ich wspomnienia ukazały się w nowym opracowaniu (Budzyński 2003: 5-7). Od tego okresu metoda ta jest wykorzystywana i doskonalona w licznych badaniach nie tylko o charakterze socjologicznym ${ }^{10}$, w tym także podejmujących problematykę zbiorowości wykluczonych i zagrożonych ekskluzją społeczną, takich jak np. migranci oraz gastarbeiterzy, ,pensjonariusze" instytucji totalnych - więzień, zakładów resocjalizacyjnych, placówek

${ }^{8}$ Badacze otrzymali 774 relacje bezrobotnych, jednak planowane wydanie dwóch kolejnych tomów nie powiodło się (Sułek 2011: 63).

9 „Kiełkują tam poglądy mocno zabarwione niezadowoleniem, a nieraz i chęcią odwetu [...]. Każdy usiłujący trzymać rękę na pulsie życia społecznego: mąż stanu, polityk partyjny, działacz społeczny powinien mieć to w pamięci swojej, że chwile takie jak dzisiejsze nie tylko doświadczą ludzi nędzą i głodem, ale nadto krzeszą w jaźniach ludzkich iskry rokoszu” (Krzywicki 1933: VI).

${ }^{10}$ Duże znaczenie dla rozwoju badań biograficznych w obszarze wykluczenia społecznego miały prace amerykańskiego socjologa i antropologa Oscara Lewisa, który w oparciu o materiały zbierane od końca lat 1950-tych w Meksyku sformułował i spopularyzował koncepcję kultury biedy jako przekazywanego z pokolenia na pokolenie pewnego wzorca życiowego i jednocześnie mechanizmu obronnego umożliwiającego biednym radzenie sobie $\mathrm{w}$ trudnej sytuacji życiowej (Lewis 1965: 25-26). 
opiekuńczo-wychowawczych, szpitali psychiatrycznych, osoby uzależnione od środków psychoaktywnych (np. Frazier 1990; Hoffman-Riem za: Riemann 2003; Riemann 1987; Prins 2008) ${ }^{11}$.

\section{ZASTOSOWANIE METODY BIOGRAFICZNEJ W BADANIACH BIEDY I WYKLUCZENIA SPOLECZNEGO W POSTRANSFORMACYJNEJ POLSCE}

Do roku 1989 w Polsce, podobnie jak w innych krajach socjalistycznych, bieda nie istniała zarówno w dyskursie publicznym, jak i naukowym. Jedną z przyczyn tego stanu rzeczy ,[było] ideologiczne embargo [...] nałożone w czasach PRL na problematykę ubóstwa, bezrobocia i nierówności społecznych"12 (Kraczla 1992 za: Tarkowska 2000: 9). Problematyka ubóstwa i wykluczenia społecznego zaczęła pojawiać się w dyskursie naukowym i publicznym w naszym kraju „w sposób oficjalny" już w pierwszych latach transformacji, kiedy to nawarstwianie się problemów społecznych i konieczność poszukiwania środków zaradczych spowodowały, że procesy pauperyzacji stały się przedmiotem pogłębionych, wieloaspektowych analiz ${ }^{13}$. W trzech socjologicznych zespołach badawczych (katowickim pod kierownictwem K. Wódz, łódzkim kierowanym przez W. Warzywodę-Kruszyńską oraz warszawskim kierowanym przez E. Tarkowską) szybko dostrzeżono możliwości analityczne wynikające $\mathrm{z}$ zastosowania metody biograficznej w badaniach biedy i towarzyszących jej problemów społecznych. Wydaje się, że pierwsze polskie wywiady biograficzne z przegranymi transformacji systemowej zebrano w latach 1995-1996 w ramach współpracy tych zespołów w międzynarodowym projekcie „Społeczna historia ubóstwa w Europie Środkowej”"14, w którym posłużono się metodą badawczą opracowaną przez D. Bertaux (1995) polegającą na „rekonstrukcji

${ }^{11}$ Bardzo interesujące prace, w których do badania problemów osób zagrożonych wykluczeniem zastosowano wywiady narracyjne, powstały w środowisku badawczym skupionym wokół F. Schütze. Ze środowiska tego wywodzą się właśnie G. Riemann oraz nieżyjący już Ch. HoffmanRiem i E.H. Prins.

${ }^{12}$ Podejmowano jednak badania $\mathrm{w}$ tej dziedzinie, dokonując szacunków udziału ludności żyjącej poniżej minimum socjalnego. Np. zjawisko biedy rozproszonej analizował w początkach lat 80. P. Gliński, jednak jego praca pozostała nieopublikowana. Badacze „oficjalnie” podejmujący problematykę ubóstwa w opisie dotkniętych nim zbiorowości zmuszeni byli posługiwać się eufemistycznymi określeniami, takimi jak np. „ludność o ograniczonych możliwościach konsumpcji” (Tarkowska 2000: 9, Mareš, Moźny 1995 za: Tarkowska 2000: 9). J. Grotowska-Leder podkreśla, że po II wojnie światowej termin bieda pojawił się po raz pierwszy w tytule pracy naukowej dopiero w 1991 r. (Grotowska-Leder 1996: 68).

${ }^{13}$ Przy czym pierwsze badania w tym zakresie miały charakter ilościowy, patrz np. S. Golinowska (red.) (1997); L. Beskid (1999).

${ }^{14}$ Kierownictwo projektu J. Szalai. 
historii rodzin, dróg i mechanizmów prowadzących do biedy, jej utrwalania i reprodukcji w kolejnych pokoleniach" (Tarkowska, Warzywoda-Kruszyńska, Wódz (red.) 2003: 13). Od tego okresu badania biograficzne biedy i wykluczenia kontynuowane są w Polsce przez niezbyt liczną zbiorowość badaczy ${ }^{15}$.

Łódzki ośrodek, któremu z racji wyjątkowego charakteru niniejszego tomu poświęcić chcemy szczególną uwagę, był jednym z pierwszych w kraju, w którym w roku 1992 z inicjatywny Wielisławy Warzywody-Kruszyńskiej podjęto badania zbiorowości zagrożonych wykluczeniem społecznym wskutek procesów pauperyzacyjnych ${ }^{16}$. Realizacja kolejnych projektów zaowocowała powstaniem socjologicznego zespołu badawczego, określanego później mianem Łódzkiej Szkoły Badań nad Biedą i Pomocą Społeczną ${ }^{17}$. Zespołem tym nieprzerwanie od 20 lat kieruje W. Warzywoda-Kruszyńska.

Stosowany $\mathrm{w}$ analizach biedy i wykluczenia społecznego, dopracowany na podstawie wieloletnich doświadczeń, schemat metodologiczny łódzkiego zespołu złożony jest z kilku etapów. Pierwszą fazę badań stanowią desk research oraz różnego rodzaju analizy statystyczne zjawisk poddanych eksploracji ${ }^{18}$. Następnie przeprowadzane są wywiady grupowe/fokusowe z ekspertami - pracownikami instytucji i służb społecznych zobowiązanych do działania wobec określonej zbiorowości, a także z przedstawicielami władz lokalnych. Otrzymany w ten sposób materiał źródłowy stanowi podstawę do identyfikacji problemów społecznych występujących w danej zbiorowości. Kolejny etap realizowanego

${ }^{15} \mathrm{~Np}$. w roku 2000 w nawiązaniu do tradycji badań przedwojennych Szkoła Główna Handlowa ponownie rozpoczęła gromadzenie pamiętników bezrobotnych. Warto zaznaczyć, że duże znaczenie dla rozwoju polskiej socjologicznej refleksji nad biedą miały seminaria prowadzone w latach 1998-2003 przez Zespół Badań nad Ubóstwem IFiS PAN (prowadzone przez E. Tarkowską i J. Czapligo-Sikorską), gromadzące badaczy tej problematyki z całego kraju.

${ }^{16}$ Pierwsze projekty realizowane przez W. Warzywodę-Kruszyńską i J. Grotowską-Leder miały charakter diagnostyczny. Dotyczyły one kategorii nowych wielkomiejskich biednych definiowanych jako zasiłkobiorcy pomocy społecznej. W latach 1993-1995, w perspektywie porównawczej, opracowano charakterystykę zubożałych gospodarstw domowych w Łodzi i Katowicach, z uwzględnieniem ich struktury i podstawowych wymiarów funkcjonowania członków tych gospodarstw (Warzywoda- Kruszyńska, Grotowska-Leder 1996).

${ }^{17} \mathrm{Na}$ przestrzeni dwudziestu lat $\mathrm{w}$ pracach zespołu uczestniczyli (w kolejności przystępowania do zespołu): J. Grotowska-Leder, J. Krzyszkowski, A. Golczyńska-Grondas, M. Potoczna, G. Mikołajczyk-Lerman, M. Rek-Woźniak, M. Petelewicz, B. Jankowski, P. Bunio-Mroczek, I. Kudlińska i A. Kacprzak.

${ }^{18}$ Analizy te np. poprzez identyfikację obszarów w przestrzeni miejskiej i (lokalnej), w której występuje nadreprezentacja ludności biednej wykorzystywane są do sporządzania map biedy i wyznaczenia ,enklaw biedy”. Samo pojęcie „enklawy biedy” wprowadzone do polskiej socjologii przez łódzki zespół jest negatywnie wartościujące, ale podobny charakter mają wszelkie inne sformułowania stosowane dla określenia zdegradowanych fragmentów przestrzeni, takie jak zubożałe sąsiedztwa, pockets of poverty, neighbourhoods of relegation (Pockets of poverty, 2010; Wacquant 2007). 
schematu stanowią wywiady biograficzne prowadzone z jednostkami lub/i członkami rodzin doświadczającymi określonych problemów ${ }^{19}$.

Źródła o charakterze biograficznym stały się znaczącym elementem stosowanej przez łódzki zespół procedury badawczej w związku z wnioskami sformułowanymi na podstawie pierwszych analiz dotyczących procesów ubożenia. Już wtedy uznano, że badania ilościowe nie dają wystarczających podstaw do zidentyfikowania i wyjaśnienia mechanizmów, czynników i zjawisk stanowiących o istocie procesów pauperyzacji w wymiarze zbiorowym i jednostkowym. W konsekwencji, w łódzkim ośrodku od połowy lat 90 . wykorzystuje się różne techniki zbierania danych, mieszczące się w ramach metody biograficznej, tj. family life histories, wywiady narracyjne, pogłębione retrospektywne wywiady biograficzne oraz analizę dokumentów osobistych gromadzonych przez różnego rodzaju instytucje (np. kartoteki pomocy społecznej, akta wychowanków domów dziecka). Do chwili obecnej w rezultacie prowadzonych przez zespół projektów powstało sześć kolekcji materiałów biograficznych:

1. Mieszkańcy łódzkich enklaw biedy 1998-1999 - zbiór obejmuje ponad 100 wywiadów typu family life histories (próba zasadnicza to 90 wywiadów) przeprowadzonych z członkami 40 rodzin klientów pomocy społecznej. Pełen case of family life history obejmował trzy pokolenia jednej rodziny, ,podstawową” grupę respondentów stanowiły osoby w wieku 40-50 lat, reprezentujące pokolenie „rodziców”, wywiady zrealizowano także z ich rodzicami oraz dorosłymi dziećmi.

2. Mieszkańcy łódzkich enklaw biedy 10 lat później - zbiór powstał na przełomie 2008/2009 roku, składają się nań wywiady typu family life histories z 90 osobami, członkami 49 rodzin, wśród nich znajdowało się 30 rodzin biorących udział w badaniach z lat 1998-1999. W kolekcji tej znalazły się wywiady z osobami reprezentującymi kolejną generację rodzin beneficjentów pomocy społecznej, która weszła w dorosłość w ostatnim dziesięcioleciu.

3. Biedni poza granicami wielkiego miasta - zbiór 30 wywiadów typu family life stories zrealizowanych z członkami różnych typów rodzin wspieranych przez pomoc społeczną w latach 2000-2003 w gminach województwa łódzkiego.

${ }^{19}$ Omawianą procedurę zastosowano w pełni w następujących projektach: „Formy ubóstwa i zagrożeń społecznych oraz ich przestrzenne rozmieszczenie w Łodzi” realizowanego w latach 1997-1998 oraz „Wzmocnić szanse i osłabić transmisje biedy wśród mieszkańców miast województwa łódzkiego" (WZLOT) przeprowadzonego w latach 2008-2010. W projekcie WZLOT schemat badawczy wzbogacony został o seminaria, w trakcie których badacze prezentowali wyniki pracownikom instytucji pomocowych i edukacyjnych oraz władzom samorządowym, uzyskując od nich dodatkowe informacje oraz informacje zwrotne. W nieco zmienionej formie (w której zamiast sporządzania map biedy wykorzystuje się analizy statystyczne) procedurę zastosowano także w badaniach zbiorowości osób opuszczających instytucje opiekuńcze i resocjalizacyjne w sposób szczególny narażonych na wykluczenie (byli wychowankowie domów dziecka; byli więźniowie). 
4. Młodzi dorośli mieszkańcy miasta postprzemysłowego - 40 biografii tematycznych skoncentrowanych wokół problematyki dziedziczenia i zmiany statusu społeczno-ekonomicznego ${ }^{20}$.

5. Nastoletni rodzice w enklawach biedy - kolekcja obejmuje 100 wywiadów biograficznych przeprowadzonych z zamieszkującymi spauperyzowane sąsiedztwa osobami, których pierwsze dziecko urodziło się przed ukończeniem 20 roku życia przez rodzica.

6. Dorośli wychowankowie placówek opiekuńczo-wychowawczych - 2011-2013 - kolekcja obejmuje 46 wywiadów przeprowadzanych z urodzonymi w latach 1959-1980 wychowankami państwowych i rodzinnych domów dziecka $^{21}$.

Ponadto, najmłodsi członkowie zespołu Iwona Kudlińska i Andrzej Kacprzak w roku 2008 przeprowadzili wywiady biograficzne z klientkami pomocy społecznej oraz osobami uzależnionymi od alkoholu stanowiące podstawę ich prac magisterskich, co wzbogaciło zestaw materiałów biograficznych łącznie o 27 wywiadów narracyjnychi tematycznych biografii ${ }^{22}$. W pewnym, szczególnym aspekcie do metody biograficznej odwoływała się w swoich badaniach J. Grotowska-Leder analizująca procesy pauperyzacji w ujęciu temporalnym. Autorka badała sekwencje wydarzeń w cyklu życia klientów pomocy społecznej ze szczególnym uwzględnieniem okresów korzystania ze wsparcia instytucjonalnego (Grotowska-Leder 2002).

Łącznie, w ramach prac zespołu, zebrano do chwili obecnej ponad 400 wywiadów o charakterze biograficznym, opracowywanych i analizowanych z zastosowaniem różnych technik, także przy użyciu programów komputerowych do analizy danych jakościowych. Uzyskany materiał badawczystał się empiryczną podstawą trzech prac doktorskich, dwóch prac magisterskich oraz licznych publikacji. Podkreślmy, że zbiory gromadzonych w zespole materiałów biograficznych stale się powiększająą.

${ }^{20}$ Projekt PROFIT (Policy Responses Overcoming Factors in the Intergenerational Inheritance of Inequalities), 6 Program Ramowy UE.

${ }^{21}$ Projekt „Zinstytucjonalizowana tożsamość? Procesy formowania się tożsamości w świetle losów biograficznych dorosłych wychowanków placówek opiekuńczo-wychowawczych" 2011-2013 finansowany ze środków Narodowego Centrum Nauki, umowa 6716/B/H03/2011/40.

${ }^{22}$ „Bałuckie klientki pomocy społecznej 2008” - kolekcja 16 tematycznych wywiadów biograficznych ukierunkowanych na kwestie wykluczenia społecznego i stygmatyzacji oraz „Biografie trzeźwiejących alkoholików 2008” - kolekcja 11 wywiadów narracyjnych z mężczyznami uczestnikami ruchu AA w Łodzi i Zduńskiej Woli.

${ }^{23}$ „Projekt»Wolność« - analiza strategii i losów życiowych byłych więźniów na terenie Łodzi. Uwarunkowania i bariery społecznej readaptacji 2011-2013" realizowany przez A. Kacprzaka powstaje na podstawie wywiadów biograficznych z mężczyznami zagrożonymi ekskluzją społeczną na skutek przebytej inkarceryzacji (zakładana liczba wywiadów to 40). Planowane są także kolejne projekty, w których wykorzystana zostanie metoda biograficzna. 


\section{ZNACZENIE BADAŃ BIOGRAFICZNYCH DOTYCZĄCYCH BIEDY I WYKLUCZENIA SPOLECZNEGO DLA ROZWOJU REFLEKSJI SOCJOLOGICZNEJ}

Dzięki wieloaspektowym analizom materiałów biograficznych poczyniono ważne ustalenia o charakterze poznawczym i metodologicznym przyczyniające się do rozwoju analiz biedy i wykluczenia społecznego oraz stanowiące istotny wkład do dyskusji toczonych w ramach innych subdyscyplin socjologii. Wydaje się, że najważniejszym wynikiem tych analiz jest zdiagnozowanie mechanizmów popadania w ubóstwo, dziedziczenia oraz utrwalania biedy i wykluczenia społecznego. Oprócz tak oczywistych czynników pauperyzacji jak niski poziom wykształcenia, brak kwalifikacji zawodowych, czy uzależnienia, ustalono, że ubożeniu sprzyja znikomy kapitał społeczny (w tym zawężenie kontaktów społecznych, brak zaplecza w trudnych sytuacjach), kulturowy, ekonomiczny i emocjonalny, brak kompetencji społecznych umożliwiających efektywne funkcjonowanie, nieudane związki małżeńskie i partnerskie, wczesne, nieplanowane macierzyństwo, doświadczenie przemocy rodzinnej w przypadku dorosłych kobiet, zachowania anormatywne w okresie adolescencji związane z procesami stygmatyzacji (uzyskanie statusu „czarnej owcy”24) oraz czynniki losowe. Biografie ujawniają sekwencje przebiegu życia, których skutkiem jest marginalność jednostki, w tym krytyczne momenty i punkty zwrotne uruchamiające trajektorię cierpienia takie jak np. rozwód, niespodziewana ciężka choroba somatyczna lub psychiczna ograniczająca sprawność jednostki, śmierć bliskich (Shaw 1966: 14; Golczyńska-Grondas 2001 i 2004; Potoczna, Tarkowska 2000, 2007; Warzywoda-Kruszyńska 2009). Czynnikami sprzyjającymi ubożeniu są również złe warunki lokalowe i zamieszkiwanie w obszarze zubożałych sąsiedztw, postrzegane potocznie raczej jako rezultat biedy, a nie jej przyczyna. Materiał biograficzny wyraźnie uwidacznia znaczenie procesów makrospołecznych w uruchamianiu mechanizmów pauperyzacyjnych. Zarówno postpegeerowscy biedni, jak i część wielkomiejskich ubogich ześlizgnęła się w biedę właśnie wskutek procesów restrukturyzacji gospodarki. Tym samym zwrócono uwagę na fakt, że procesy transformacji ustrojowej przyczyniły się szczególnie do ubożenia jednostek, które w okresie PRL-u nie funkcjonowały w nieformalnym obiegu ekonomicznym. Na przykład, mieszkańcy PGR-ów i łódzkie włókniarki w podobny sposób ,padły ofiarą" decyzji o charakterze polityczno-gospodarczym, podejmowanych w początkach lat 90. XX w., bez jakiejkolwiek refleksji na temat przyszłości osób zatrudnionych w likwidowanych zakładach (Warzywoda-Kruszyńska 1996: 55; Tarkowska 2007: 113).

\footnotetext{
${ }^{24}$ Zjawisko charakterystyczne raczej dla mężczyzn niż kobiet.
} 
Na podstawie badań biograficznych czterech generacji rodzin, polscy socjologowie ubóstwa dowiedli istnienia procesu międzygeneracyjnej transmisji biedy i problemów społecznych, ukazali specyfikę tego procesu i jego mechanizmy. Istotne znaczenie $\mathrm{w}$ procesie określanym jako reprodukcja biedy (Karwacki 2006: 161) mają grupy społeczne, przede wszystkim rodzina. Z jednej strony w zbiorowości ubogich mieszczą się „dynastie” spauperyzowanych rodzin, w których bieda przekazywana jest z pokolenia na pokolenie. Dzieci w nich dorastające „oswojone są” z ubóstwem od najmłodszych lat życia, dziedziczą zachowania, postawy, strategie życiowe rodziców i dziadków, przekazując je następnie swoim potomkom. $Z$ drugiej strony, w zbiorowościach tych mamy do czynienia $\mathrm{z}$ rodzinami, w których proces dziedziczenia biedy przerwany został w przypadku jednej generacji, powracając w kolejnym pokoleniu. Narratorzy reprezentujący najstarsze pokolenie badanych łódzkich rodzin wywodzili się z biedoty wiejskiej. W okresie socjalizmu osoby takie (migrujące do Łodzi w międzywojniu lub w latach 40. i 50.) współtworzyły wielkomiejską klasę robotniczą, w związku z tym ich sytuacja materialna była stosunkowo dobra i stabilna. Jednak ich dorosłe dzieci w warunkach transformacji systemowej „nie poradziły sobie” na restrukturyzującym się rynku pracy, w konsekwencji bieda ponownie stała się podstawowym doświadczeniem życiowym tych osób i ich rodzin. Arkadiusz Karwacki (2006) wykorzystujący w swoich badaniach cases history of family wskazał z kolei na istotne znaczenie grupy rówieśniczej dla procesów transmisji ubóstwa w środowisku postpegeerowskim. Funkcjonowanie w takich grupach, (stanowiących dla młodych ludzi często jedyne źródło wsparcia), poprzez naśladownictwo anormatywnych zachowań dorosłych i równolatków przyczynia się według tego badacza do „utrwalania w młodych członkach społeczności [specyficznych] »treści wychowawczych «" (Karwacki 2006: 169-170). W sposób oczywisty, znaczenie w procesie transmisji ubóstwa ma także grupa sąsiedzka, która „edukuje” nowych mieszkańców „enklaw” w zakresie wzorów zachowań i strategii życiowych umożliwiających przetrwanie poza mainstream society.

Materiały biograficzne stanowią także podstawę do weryfikacji tezy o utrwalaniu się i pogłębianiu ubóstwa, zwłaszcza biedy skoncentrowanej przestrzennie. Bogdan Jankowski gromadzący family-life histories w łódzkich rodzinach zamieszkujących ,enklawy biedy”, w ramach realizowanych w latach 2008-2009 badań panelowych ${ }^{25}$, wykazał, że na przestrzeni minionego dziesięciolecia sytuacja życiowa respondentów nie uległa zmianie, a przedstawiciele najmłodszego pokolenia, które w „międzyczasie” wkroczyło w dorosłość, kontynuują trajektoryjne losy poprzednich generacji (Jankowski, Warzywoda-Kruszyńska 2010: 13-14).

\footnotetext{
${ }^{25}$ Kolekcja wywiadów „Mieszkańcy łódzkich enklaw biedy 1988-1999”.
} 
Nieco odmienne wyniki uzyskała E. Tarkowska, która w roku 2005 powróciła do badanych wcześniej rodzin postpegeerowskich przeprowadzając wywiady retrospektywne także z przedstawicielami najmłodszego pokolenia. Części młodych mieszkańców osiedli postpegeerowskich udało się uporać z biedą dzięki zdobytemu wykształceniu oraz strategii polegającej na podejmowaniu pracy zarobkowej legalnej lub w szarej strefie. Mimo tego Tarkowska stwierdziła, że prowadzone przez nią badania ukazały mechanizmy ciągłości, trwałości, a nawet pogłębiania się ubóstwa (Tarkowska 2007: 138, i in.). Podkreślmy w tym miejscu, że materiały biograficzne ukazują niezwykle wyraziście sytuację jednostek i rodzin ,zatrzaśniętych" w biograficznej pułapce biedy i wykluczenia społecznego wskutek procesów makro- i mezzostrukturalnych. Uwidaczniają one degradujący wpływ ubóstwa na jednostki, które we wcześniejszym okresie życia „dobrze sobie radziły", potwierdzając znaną nie tylko badaczom wykluczenia społecznego tezę, głoszącą, że „ludzie pozostający w stanie długotrwałego stresu i deprywacji uczą się życia w upokarzających warunkach" (Knop, Piłat 2010: 121).

Historie życia ubogich rodzin,,rzuciły światło" na mechanizm tworzenia polskich postransformacyjnych wielkomiejskich enklaw biedy. Oryginalną koncepcję sformułowała w tej kwestii W. Warzywoda-Kruszyńska dowodząc, że zubożałe sąsiedztwa powstały w Łodzi w wyniku nakładających się na siebie procesów dezindustrializacji, dewelferyzacji ${ }^{26}$ i dezinstytucjonalizacji dotykających jednostki i rodziny w okresie transformacji systemowej (Warzywoda-Kruszyńska, Golczyńska-Grondas 2010: 30-32). Koncepcja ta doskonale uzupełnia dotychczasowe ustalenia dotyczące miejskich gett biedy poczynione m.in. przez W. J. Wilsona i L. Wacquanta (np. Wilson 1987; Wacquant 2008). Dodajmy, że nierzadko w wywiadach biograficznych odnajdujemy fragmenty świadczące o niebagatelnym udziale praktyk stosowanych przez instytucje edukacyjne i pomocowe w procesach transmisji i utrwalania się ubóstwa, w tym w powstawaniu i utrzymywaniu się zubożałych sąsiedztw.

Wywiady biograficzne ukazują zróżnicowanie świata biedy i procesów wykluczenia społecznego, jakim podlegają mieszkańcy tego świata. Wśród badaczy ubóstwa powszechnie znane jest rozróżnienie biedy „starej”, związanej z niezaradnością, niepełnosprawnością, czy też określonym stylem życia i „nowej" - stanowiącej efekt transformacji o charakterze polityczno-gospodarczym. Stereotypowo wyróżnia się biedę ,porządną”, gdzie podstawowym problem są „tylko” ograniczone możliwości zaspokajania potrzeb życiowych i biedę „spatologizowaną", związaną z zachowaniami anormatywnymi jednostek i dysfunkcjami rodziny (np. Potoczna 1998: 68). Historie życia ujawniają, że rzeczywista

${ }^{26}$ Dewelferyzacja wg Warzywody Kruszyńskiej oznacza wycofywanie się władz państwowych z subsydiowania usług społecznych (Warzywoda-Kruszyńska, Golczyńska-Grondas 2010: 30). 
charakterystyka tego świata jest o wiele bardziej skomplikowana, zróżnicowana przede wszystkim w wymiarze geograficznym i przestrzennym (miasto - wieś) (np. Warzywoda-Kruszyńska, Grotowska-Leder, Krzyszkowski 2003), oraz temporalnym (bieda przelotna, okazjonalna, uporczywa, chroniczna, permanentna) (Grotowska-Leder 2002: 201-239). Obraz ubóstwa warunkowany jest także strukturą rodziny, wykształceniem i stanem zdrowia jej członków, czy też funkcjonowaniem jednostek na rynku pracy. W każdej badanej zbiorowości można prawdopodobnie spotkać zarówno takie same, jak i swoiste typy biedy. Na przykład E. Tarkowska w badaniach biedy popegeerowskiej wyróżnia biedę głęboką, biedę utrwaloną - bez nadziei, biedę nową, płytką przejściową, biedę nową przekazywaną następnemu pokoleniu, dawną biedę utrwaloną w nowych warunkach i biedę powracającą (Tarkowska 2000: 61-89). W projekcie WZLOT analizowano z kolei ujawniające się w biografiach przedstawicieli badanych zbiorowości wymiary wykluczenia: ekonomiczny, przestrzenny, edukacyjny, relacyjny, kulturowy, zdrowotny i partycypacyjny (np. Golczyńska-Grondas 2008: 25-26; Bunio-Mroczek, Warzywoda-Kruszyńska 2010: 15-24). Podobnie jak inne wywiady biograficzne, także wywiady z osobami spauperyzowanymi ujawniają ich style życia, zarówno w wymiarze codziennych zachowań, jak i strategii adaptacyjnych stosowanych w warunkach niedostatku, np.: zorientowaną na teraźniejszość strategie życia $\mathrm{z}$ dnia na dzień, strategię zorientowaną na zasiłki, strategię zorientowaną na zatrudnienie oraz strategię zorientowaną na przyszłość, w której rodzina czyni wysiłki na rzecz poprawy losu kolejnego pokolenia poprzez zdobywanie wykształcenia (Potoczna 1998: 83-90; Tarkowska 1999: 34; Grotowska-Leder 2002: 201-239). Na podstawie materiału biograficznego stworzyć można katalog różnorodnych problemów społecznych związanych z biedą i wykluczeniem, takich jak dezorganizacja i dysfunkcjonalność rodziny, niedostosowanie społeczne dzieci i młodzieży, uzależnienia, przemoc, przestępczość. Socjologiczny obraz społecznych światów ubóstwa i ich „mieszkańców” staje się szczególnie wyrazisty, w przypadku prac, których autorzy podejmują się analiz kontrastywnych, gdzie historie życia „nowych biednych" ukazane są na przykład w zestawieniu z biografiami przedstawicieli tworzącej się klasy średniej (Palska 2002).

Stosowanie metody biograficznej, co oczywiste, umożliwia pogłębione analizy indywidualnych biografii biednych, ujawniając przebieg losów życiowych wraz z ich uwarunkowaniami osobowościowymi i strukturalnymi. Wywiady biograficzne dają podstawę do rekonstrukcji kariery edukacyjnej i zawodowej, a także kariery klienta instytucji pomocy społecznej, bliskiej - jak sądzimy - koncepcji kariery moralnej E. Goffmana (Goffman 2011: 126-166) oraz wyraźnie uwidaczniają, w jaki sposób bieda doświadczana jest w kolejnych fazach cyklu życia - nie tylko w dorosłości, ale także w dzieciństwie i adolescencji, oraz 
W starości ${ }^{27}$. Zjawisko juwenilizacji biedy ${ }^{28}$ uwypukliły analizy biografii spauperyzowanych osób prowadzone przez W. Warzywodę-Kruszyńską. Autorka ta wskazuje, że bieda doświadczana w dzieciństwie ma determinujący wpływ na dalszy przebieg życia i podkreśla, że nawet jeżeli uznać by wątpliwą tezę o odpowiedzialności osoby biednej za jej sytuację, to nie ma ona zastosowania $\mathrm{w}$ przypadku dzieci, które nie ponoszą winy za warunki, w jakich żyją (Warzywoda-Kruszyńska 1999, 2008). O znaczeniu niedostatku w okresie dzieciństwa dla odtwarzania błędnego koła biedy w środowisku wielkomiejskim w odniesieniu do badań biograficznych pisali także inni badacze z zespołu W. Warzywody-Kruszyńskiej - np. autorki tego tekstu oraz ostatnio P. Bunio-Mroczek i B. Jankowski (Golczyńska-Grondas 2004; Potoczna, Warzywoda-Kruszyńska 2009; Bunio-Mroczek, Warzywoda-Kruszyńska 2010; Jankowski, Warzywoda-Kruszyńska 2010). E. Tarkowska, a później A. Karwacki ukazali z kolei specyfikę dzieciństwa w osiedlach popegeerowskich (Tarkowska 2000, 2007; Karwacki 2006). Obraz dzieciństwa przebiegającego w dysfunkcyjnych rodzinach, w złych warunkach materialnych wyłania sięz wywiadów biograficznych prowadzonych w zbiorowości wychowanków domów dziecka (Giermanowska, Racław-Markowska 2007; Golczyńska-Grondas 2012). Z tych analiz wynika, że bieda najmłodszych związana jest $\mathrm{z}$ wielowymiarowym upośledzeniem oraz znacząco przyczynia się do skrócenia biograficznej fazy dzieciństwa poprzez przedwczesne podejmowanie obowiązków przynależnych w naszym społeczeństwie osobom dorosłym - przejęcie odpowiedzialności za wykonywanie prac domowych, opiekę nad młodszym rodzeństwem, dorywcze, a później bardziej regularne prace zarobkowe.

Chociaż w chwili obecnej w Polsce, zgodnie ze statystykami, osoby w wieku postprodukcyjnym nie są zaliczane do zbiorowości w sposób szczególny dotkniętych biedą, historie życia obrazują specyfikę doświadczania ubóstwa w fazie starości. W biednych rodzinach sytuacja seniorów uwarunkowana jest sytuacją materialną i życiową młodszych pokoleń. Zarówno w mieście, jak i na wsi najstarsze pokolenie pełni wobec swoich dorosłych dzieci i wnuków rolę służebną, udzielając im systematycznego wsparcia w wymiarze ekonomicznym (utrzymując bezrobotnych członków rodziny), mieszkaniowym (przyjmując pod swój dach nieposiadające mieszkania wnuki) i opiekuńczo-wychowawczym, co ogranicza możliwości zaspokajania indywidualnych potrzeb seniorów (Laskowska-Otwinowska 2000; Potoczna, Warzywoda-Kruszyńska 2009).

${ }^{27} \mathrm{~W}$ tekście odnosimy się tytułem przykładu do dwóch faz: dzieciństwa i starości, pomijając kwestię doświadczania biedy w okresie dorosłości.

${ }^{28}$ Pojęcie juwenilizacji biedy wprowadziła do polskiej socjologii W. Warzywoda-Kruszyńska. Oznacza ono, że dzieci nadreprezentowane są w populacji ludzi biednych w stosunku do ich udziału w populacji ogółem (Warzywoda-Kruszyńska 1999: 87). 
Analizy indywidualnych biografii ukazują także specyfikę ról społecznych w świecie ubóstwa. Role rodzinne, zawodowe i inne często realizowane są przez osoby spauperyzowane w sposób nieco odmienny od standardów i wzorów obowiązujących w głównym nurcie życia społecznego (Golczyńska-Grondas 2004; Potoczna, Warzywoda-Kruszyńska 2009). Zwraca również uwagę odzwierciedlający się $\mathrm{w}$ materiałach biograficznych szczególny przebieg procesów tożsamościowych w wymiarze indywidualnym i kolektywnym, związany z procesami marginalizacji społecznej, izolacji, stygmatyzacji oraz autowykluczenia i autostygmatyzacji (Tarkowska 1999: 5).

Zastosowanie metody biograficznej w badaniach biedy i powiązanego $\mathrm{z}$ nią wykluczenia społecznego przyczynia się także do poszerzenia zasobów wiedzy i wzbogacenia o nowe wątki dyskusji toczonych w obrębie innych subdyscyplin socjologii. I tak na przykład biografie jednostek i family-life histories $\mathrm{w}$ pewnym zakresie weryfikują koncepcje dotyczące usytuowania biednych w strukturze społecznej (Kruszyńska 1998a). Już w latach 90. badania biograficzne skłoniły część polskich badaczy do krytycznej refleksji dotyczącej koncepcji underclass i w rezultacie rezygnacji z używania pojęcia podklasy w związku z jego silnie stygmatyzującym charakterem. Socjologia rodziny potencjalnie wzbogacona została o wątki dotyczące pewnych odmienności struktury i funkcji rodziny oraz realizacji ról rodzinnych w warunkach ubóstwa. Zebrany materiał pozwala badaczom biedy na włączenie się w dyskusje na temat nierówności płci i ich znaczenia w obszarze gender studies. W badaniach biedy znajdziemy bowiem potwierdzenie społecznego upośledzenia kobiet związanego ze zjawiskiem feminizacji ubóstwa, oznaczającym nie tylko ich nadreprezentację w populacji biednych, ale także szczególną rolę kobiet przejmujących odpowiedzialność za funkcjonowanie ubogiej rodziny (m.in.: Warzywoda-Kruszyńska, Grotowska-Leder 1996: 129-165; Potoczna, Warzywoda-Kruszyńska 2009; Grotowska-Leder, Kudlińska 2011). Jednakże, analizy biograficzne udowodniły, że bieda ma także „twarz mężczyzny" ponoszącego konsekwencje procesów pauperyzacyjnych w sposób odmienny, lecz równie dotkliwy jak kobiety (Golczyńska-Grondas 2004; Tarkowska 1999a). Żywić można nadzieję, że ustalenia poczynione w zakresie biograficznych badań biedy i ubóstwa przyczynić się mogą do przełamywania stereotypów niezmiennie sytuujących kobiety w roli pasywnych ofiar, a mężczyzn aktywnych sprawców przemocy. Z całą pewnością stwierdzić można, że zarówno biedne kobiety, jak i biedni mężczyźni w równym stopniu są ofiarami przemian o charakterze makrostrukturalnym.

W sposób naturalny badacze biografii ludzi żyjących w ubóstwie włączają się do dyskusji na temat rozwiązań programowych w ramach polityki społecznej. Z jednej strony analiza historii życia umożliwia wskazywanie krytycznych 
punktów biografii, w których jednostka/rodzina powinna uzyskać wsparcie instytucjonalne. $\mathrm{Z}$ drugiej strony biografie traktować można jako rodzaj lustra, w którym odbija się interwencja służb społecznych ukazując znaczenie wsparcia instytucjonalnego dla przebiegu życia jednostki, funkcjonowania rodziny, a nawet całej społeczności. Podkreślić należy, że ocena podejmowanych działań nie zawsze jest pozytywna. Na przykład panelowe badania biograficzne w łódzkich spauperyzowanych rodzinach udowodniły, iż w ich przypadku stan ubóstwa utrwalił się, a nawet pogłębił, mimo działań podejmowanych wobec nich przez instytucje pomocowe i edukacyjne (Jankowski, WarzywodaKruszyńska, 2010: 48).

\section{PODSUMOWANIE}

Jak wynika z powyższych rozważań zastosowanie metody biograficznej w analizach ubóstwa i wykluczenia społecznego pozwala na uzyskanie pogłębionego, wielowymiarowego obrazu związanych z nimi mechanizmów i procesów, przyczyniając się także do rozwoju nauk społecznych w aspekcie bardziej ogólnym. Podkreślić należy, że szczególna sytuacja życiowa i emocjonalna respondentów doświadczonych w toku swojego życia traumatycznymi wydarzeniami oraz niesymetryczna relacja między badaczem a badanym $\mathrm{w}$ analizach zbiorowości defaworyzowanych społecznie skutkuje doskonaleniem metod, narzędzi i technik stosowanych przez socjologów. Badania biedy i wykluczenia społecznego nieuchronnie związane są także z koniecznością rozstrzygania dylematów etycznych w związku z niebezpieczeństwem uruchomienia lub pogłębienia procesów stygmatyzacyjnych $\mathrm{w}$ wyniku prowadzenia badań i publikacji ich wyników ${ }^{29}$ i - choć nie można bagatelizować znaczenia zagrożeń tego typu - podkreślić należy, że w porównaniu do innych technik gromadzenia danych umiejętnie prowadzone badania biograficzne stwarzają możliwość dogłębnej analizy problemów społecznych dotykających zbiorowości defaworzyzowane oraz upodmiotowienia osób, które w badaniach tych biorą udział jako narratorzy i respondenci ${ }^{30}$.

${ }^{29} \mathrm{Ze}$ względu na ograniczenia dotyczące objętości tekstu nie podejmujemy szerzej kwestii metodologicznych i etycznych. Omówienia i komentarze ich dotyczące znajdzie Czytelnik w niektórych pracach zamieszczonych w spisie bibliograficznym (np. Golczyńska-Grondas 2009; Tarkowska 2000).

${ }^{30}$ Wśród polskich badaczy biografii toczy się dyskusja na temat określeń stosowanych wobec osób opowiadających o swoich historiach życia. Przeważnie używa się terminu „narrator”, uznać jednak można rozróżnienie ról narratora w klasycznym wywiadzie narracyjnym i respondenta w pogłębionym, swobodnym wywiadzie biograficznym. 


\section{BIBLIOGRAFIA}

Bertaux D. (1995), Case histories of families as a method in poverty research, [w:] J. Szalai (red.), The Social History of Poverty in Central Europe, Working Papers. Budapest: Max Weber Foundation for the Study of Social Initiatives.

Budzyński A. (2003), Wstęp, [w:] Pamiętniki bezrobotnych, t. I, Warszawa: Wydawnictwo SGH.

Bunio-Mroczek P., Warzywoda-Kruszyńska. W. (2010), Wczesne rodzicielstwo jako zagrożenie bieda $i$ wykluczeniem społecznym. Łódź: Wydawnictwo Biblioteka, Instytut Socjologii Uniwersytetu Łódzkiego, Fundacja Instytut Inicjatyw Społecznych.

Burgess E.W. (1966), Discussion, [w:] C.S. Shaw (1966), The Jack-Roller. A Delinquent Boy's Own Story, Chicago and London: Chicago University Press.

Czarnowski S. (1982), Ludzie zbędni w stużbie przemocy, [w:] S. Czarnowski, Wybór pism socjologicznych, Warszawa: Książka i Wiedza.

Dobrowolska D. (1992), Przebieg życia - fazy-wydarzenia, „Kultura i Społeczeństwo”, nr 2.

Frazier Ch.E. (1990), Znaczenie dokumentów osobistych i biografii dla teorii i praktyki badawczej kryminologii, [w:] J. Włodarek, M. Ziółkowski (red.), Metoda biograficzna w socjologii, Warszawa-Poznań: PWN.

Frieske K. (red.) (1999), Marginalność i procesy marginalizacji, Opracowania PBZ, Warszawa: Instytut Pracy i Spraw Socjalnych.

Geremek B. (1989), Litość i szubienica. Dzieje nędzy i miłosierdzia, Warszawa: Czytelnik.

Giermanowska E., Racław-Markowska M. (2007), Losy usamodzielnionych wychowanków domów dziecka, [w:] E. Tarkowska (red.), Ubóstwo i wykluczenie społeczne młodzieży, Warszawa: Instytut Pracy i Spraw Socjalnych.

Goffman E. (2011), Instytucje totalne. O pacjentach szpitali psychiatrycznych i mieszkańcach innych instytucji totalnych, Sopot: Gdańskie Wydawnictwo Psychologiczne.

Golczyńska-Grondas A. (2004), Mężczyźni z enklaw biedy. Rekonstrukcja petnionych ról społecznych, Łódź: Wydawnictwo Absolwent.

Golczyńska-Grondas A. (2009), Researching children from the enclaves of poverty in the city of Lodz, Poland. Methodological and ethical dilemmas, Lisbon: CD ESA

Golczyńska-Grondas A. (2012), Biografie dorostych wychowanków domów dziecka. Próba analizy socjologicznej, „Acta Universitatis Lodziensis”, Folia Sociologica 41.

Golinowska S. (red.) (1997), Polska bieda II. Kryteria. Ocena. Przeciwdziałanie, Warszawa: Instytut Pracy i Spraw Socjalnych.

Grotowska-Leder J. (1996), „Nowa bieda” w Polsce, [w:] W. Warzywoda-Kruszyńska, J. Grotowska-Leder (red.), Wielkomiejska bieda w okresie transformacji, Łódź: Instytut Socjologii Uniwersytetu Łódzkiego.

Grotowska-Leder J. (2002), Fenomen wielkomiejskiej biedy. Od epizodu do underclass, Łódź: Wydawnictwo Uniwersytetu Łódzkiego.

Grotowska-Leder J. (2003), Oblicza biedy w gminach. Warunki życia biednych mieszkańców gmin, [w:] W. Warzywoda-Kruszyńska, J. Grotowska-Leder, J. Krzyszkowski, Lokalna polityka wobec biedy. Bieda poza granicami wielkiego miasta, Łódź: Instytut Socjologii Uniwersytetu Łódzkiego.

Grotowska-Leder J., Kudlińska I. (2011), Feminizacja biedy w perspektywie analiz jakościowych welfare dependency, [w:] K. Slany, J. Struzik, K. Wojnicka (red.), Gender w społeczeństwie polskim, Kraków: Nomos.

Hałas E. (1994), Obywatelska socjologia szkoły chicagowskiej, Lublin: Wydawnictwo KUL. 
Jankowski B., Warzywoda-Kruszyńska W. (2010), Mieszkańcy łódzkich enklaw biedy 10 lat później, Łódź: Wydawnictwo Biblioteka, Instytut SocjologiiUniwersytetu Łódzkiego.

Karwacki A. (2006), Błędne koło. Reprodukcja kultury podklasy społecznej, Toruń: Wydawnictwo Uniwersytetu Mikołaja Kopernika.

Knop J., Piłat R. (2010), Stosunek do przyszłości na przykładzie „Pamiętników bezrobotnych” (lata 1999-2001), „Kultura i Społeczeństwo”, nr 3.

Kowalak T. (1998), Marginalność i marginalizacja społeczna, Warszawa: Dom Wydawniczy Elipsa.

Krzywicki L. (1933), Wstęp, [w:] Pamiętniki bezrobotnych, Warszawa: Instytut Gospodarstwa Społecznego.

Laskowska-Otwinowska J. (2000), Człowiek stary w ubogiej rodzinie polskiej wsi współczesnej, [w:] E. Tarkowska (red.), Zrozumieć biednego, Warszawa: Typografika.

Leś E. (2000), Od filantropii i pomocniczości. Studium porównawcze rozwoju i działalności organizacji społecznych, Warszawa: Dom Wydawniczy Elipsa.

Lewis O. (1964), Sanchez i jego dzieci. Autobiografia rodziny meksykańskiej, Warszawa: PIW.

Pockets of poverty. The challenge for schools with small proportions of FSM pupils, Department of Education, March 2010, www.education.gov.uk/publications/standard/SchoolsSO/Page16/ DCSF-00170-2010 [pobrano 28 lutego 2013]

Palska H. (2002), Bieda i dostatek. O nowych stylach życia w Polsce końca lat dziewięćdziesiatych, Warszawa: Wydawnictwo IFiS PAN.

Potoczna M., Warzywoda-Kruszyńska W. (2009), Kobiety z tódzkich enklaw biedy. Bieda w cyklu życia i międzypokoleniowym, Łódź: Wydawnictwo Uniwersytetu Łódzkiego.

Prins E.H. (2008), ,,Maturing Out” and the Dynamics of the Biographical Trajectories of Hard Drug Addicts, „Forum Qualitative Social Research”, vol. 9, no. 1, art 30.

Riemann G. (2003), A Joint Project Against the Backdrop of a Research Tradition: An Introduction to „Doing Biographical Research”, „Forum Qualitative Social Research”, vol. 4 no. 3 , art. 18 .

Riemann G. (1987), Das Fremdwerden der eigenen Biographie. Narrative Interviews mitpsychiatrischenPatienten, Munich: Wilhelm Fink Verlag.

Shaw C.S. (1966), The Jack-Roller. A Delinquent Boy's Own Story, Chicago and London: Chicago University Press.

Sułek A. (2011), Badania w Marienthalu i wspótczesne im badania nad bezrobociem w Polsce, [w:] A. Sułek, Obrazy z życia socjologii w Polsce, Warszawa: Oficyna Naukowa.

Szacki J. (2005), Historia myśli socjologicznej. Wydanie nowe, Warszawa: Wydawnictwo Naukowe PWN.

Szczepański J. (1976), Dzieło W.I. Thomasa i F. Znanieckiego w rozwoju socjologii, [w:] Chtop polski w Europie i Ameryce, Warszawa: Ludowa Spółdzielnia Wydawnicza.

Tarkowska E. (1999), Świat społeczny biednych. Koncepcja kultury ubóstwa, „Polityka Społeczna”, nr 11-12.

Tarkowska E. (1999a), Kobiety, mężczyźni i bieda, „Res Publica Nova”, nr 9.

Tarkowska E. (red.) (2000), Zrozumieć biednego. O dawnej i obecnej biedzie w Polsce, Warszawa: Typografika.

Tarkowska E. (2006), Ubóstwo i wykluczenie społeczne. Koncepcje i polskie problemy, [w:] J. Wasilewski (red.), Wspótczesne społeczeństwo polskie. Dynamika zmian, Warszawa: Wydawnictwo Naukowe Scholar.

Tarkowska E. (2007), Dziedziczenie biedy $i$ wychodzenie z biedy w rodzinach byłych pracowników PGR-ów, [w:]: Ubóstwo i wykluczenie społeczne młodzieży, Warszawa: IPiSS 
Tarkowska E., Warzywoda-Kruszyńska W. (2003), Wstęp, [w:] E. Tarkowska, W. Warzywoda-Kruszyńska, K. Wódz (red.), Biedni o sobie $i$ o swoim życiu, Katowice-Warszawa: Wydawnictwo Śląsk.

Thomas W.I., Znaniecki F. (1976), Chłop polski w Europie i Ameryce, Warszawa: Ludowa Spółdzielnia Wydawnicza.

Wacquant L. (2007), Urban Outcast. A Comparative Sociology of Advanced Marginality. Cambridge: Polity Press.

Warzywoda-Kruszyńska W. (1996), Historia i rozumienie biedy, [w:] W. Warzywoda-Kruszyńska, J. Grotowska-Leder, Wielkomiejska bieda w okresie transformacji, Łódź: Instytut Socjologii Uniwersytetu Łódzkiego.

Warzywoda-Kruszyńska W. (1999), Dorastać w biedzie - obrazy z życia różnych pokoleń łodzian, [w:] W. Warzywoda-Kruszyńska (red.), (Żyć) na marginesie wielkiego miasta, Łódź: Instytut Socjologii Uniwersytetu Łódzkiego.

Warzywoda-Kruszyńska W. (1998a), Wielkomiejscy biedni - formująca się underclass? Przypadek klientów pomocy społecznej, „Kultura i Społeczeństwo”, nr 2.

Warzywoda-Kruszyńska W. (2001), Modele wyjaśniania biedy i sposoby konceptualizacji biednych, [w:] W. Warzywoda-Kruszyńska (red.), Żyć i pracować w enklawach biedy, Łódź: Instytut Socjologii Uniwersytetu Łódzkiego.

Warzywoda-Kruszyńska W. (2001b), Wstęp, [w:] W. Warzywoda-Kruszyńska (red.), (Żyć) Na marginesie wielkiego miasta, Łódź: Instytut Socjologii Uniwersytetu Łódzkiego.

Warzywoda-Kruszyńska W., Grotowska-Leder J., Krzyszkowski J. (2003), Lokalna polityka wobec biedy. Bieda poza granicami wielkiego miasta, Łódź: Instytut Socjologii Uniwersytetu Łódzkiego.

Warzywoda-Kruszyńska W. (2008), Dzieci żyjące w biedzie - dzieci krzywdzone, „Dziecko Krzywdzone", nr 2.

Warzywoda-Kruszyńska W., Golczyńska-Grondas A. (2010), Wzmocnić szanse i osłabić transmisję biedy wśród mieszkańców miast województwa łódzkiego - WZLOT. Raport końcowy + Rekomendacje, Łódź: Wydawnictwo Biblioteka, Instytut Socjologii Uniwersytetu Łódzkiego.

Wilson W.J. (1987), The Truly Disadvantaged. The Inner City, the Underclass, the Public Policy, Chicago: University of Chicago Press.

Agnieszka Golczyńska-Grondas, Matgorzata Potoczna

\section{BIOGRAPHICAL RESEARCH IN THE ANALYSIS OF POVERTY AND SOCIAL EXCLUSION}

(Summary)

Since early 1990. the members of sociological team led by professor WielisławaWarzywodaKruszyńska have been gathering narrative and biographical interviews with individuals and families, marginalized due to their inter-generationally inherited poverty. The paper treats on biographical data application in sociological studies of poverty and social exclusion - recognized processes 
and phenomena, and their cognitive importance. Multifaceted analysis of neighbourhood of relegations, family life of the poor, collective and individual dimensions of pauperization, social roles, individual and collective identities are pursued on the basis of biographical data. The results of the biographical research provoke thoughts about the institutional intervention and its influence on the social world of poverty. 